\title{
Evaluation of cell free circulating plasma DNA in prostate cancer
}

\author{
Karima M. Sweify ${ }^{1}$, AmalFawzy $^{2}$, Hany M. El-Fayoumy ${ }^{3}$, Nagwa Nofal ${ }^{1}$ \\ ${ }^{1}$ Women's College for Arts, Science and Education, Ain Shams University. \\ ${ }^{2}$ National Cancer Institute, Cairo University' \\ ${ }^{3}$ Faculty of Medicine Kasr Al-Ainy, Cairo University.
}

\begin{abstract}
Background: Prostate cancer (PC) is the most common cancer affecting men, it accounts for $29 \%$ of all male cancer and $11 \%$ of all male cancer related deaths. DNA is normally released from an apoptotic source which generates small fragments of cell-free DNA, whereas cancer patients have cell-free circulating DNA that originated from necrosis, autophagy, or mitotic catastrophe, which produce large fragments. Aim of work: Differentiate the cell free DNA levels (CFDNA) and its integrity in prostate cancer patients and control group composed of benign prostate hyperplasia (BPH) and healthy persons. Methodology: cf-DNA levels were quantified by real-time PCR amplification in prostate cancer patients $(\mathrm{n}=50),(\mathrm{BPH})$ benign prostate hyperplasia $(n=25)$ and healthy controls $(n=30)$ using two sets of ALU gene (product size of $115 \mathrm{bp}$ and 247-bp) and its integrity was calculated as a ratio of qPCR results of 247 bp ALU over 115 bp ALU. Results: Highly significant levels of cf-DNA and its integrity in PC patients compared to BPH. Twenty-eight (56\%) patients with prostate cancer had bone metastasis. ALU115 q PCR is superior to the other markers in discriminating metastatic patients with a sensitivity of $96.4 \%$ and a specificity of 86.4\% (AUC $=0.981$ ) Conclusion: ALU115 q PCR could be used as a valuable biomarker helping in identifying high risk patients, indicating early spread of tumor cells as a potential seed for future metastases.
\end{abstract}

Key words: metastatic prostate cancer, benign prostatic hyperplasia, circulating cell free DNA

\section{Introduction}

Prostate cancer (PC) is a common health problem. It starts to develop at the age 50 years, the highest level reaching $60-70$ years of age. The highest incidence is recorded in US and Canada, Australia, northern and central Europe. The lowest rates are in southeastern, south - central, Asia and northern Africa (ACS, 2010).

Risk factors of PC are classified as endogenous, that include family history, hormones, race, aging oxidative stress. Exogenous risk factors consist of diet, obesity environmental agent, sexually transmitted infections and occupation and other factors such as, smoking energy intake, marital status, vasectomy, social factors and physical

\section{Corresponding author nagwa.nofal@hotmail.com}


activity(Bostwich et al., 2004; ACS, 2012 ; Cancer- Net Editorial Board, 2016).Prostate gland secretes and produces into the semen and the blood stream a serine protease which is known as prostate specific antigen (PSA). It hydrolyzes the sperm motility inhibitor semenogelin in semen(Barrett and Colleagues, 2010). The elevated plasma PSA occurs in PC, so it is widely used as a screening test for diagnosis and monitoring the tumor progression in patient. However PSA levels may elevate in other prostatic disease ( Soutoet al.,2006). So, it was replaced by the measurement of $\mathrm{CF}$ - DNA which has received increasing attention as a non-invasive cancer biomarker.

Nowadays most studies employed a more sensitive quantitated- Real time PCR to compare the concentration of CF-DNA in PC patients and healthy controls (Gordian et al., 2010; Delgado et al., 2013). Such technique is carried out using ALU $115 \mathrm{bp}$ and ALU $247 \mathrm{bp}$ primers. The ratio of ALU 247 to ALU 115 reflected the integrity of plasma CF-DNA.So far, the measurement of the plasma DNA integrity may serve as a useful marker for the detection and monitoring of patient with different kinds of cancer. The studies also show that adding of CF-DNA to PC screening can reduce the number of unnecessary prostate biopsy (Cao et al., 2006; Gordian et al., 2010). Concerning the CF-DNA,Jahr et al.(2001)showed that apoptosis and necrosis of tumor cells contribute to the increase in CF-DNA in patients with cancer. Various authors came to the same conclusions in tumor tissue DNA and plasma DNA in PC (Delgado et al., 2013; Feng et al., 2013 and Elabbady et al., 2014). Similar results were obtained in different cancers, Umetaniet al. (2006a) in breast cancer, Sai et al. (2007) in gastric cancer,Chan et al.( 2008) in nasopharyngeal carcinoma patients and Schwarzenbach et al, (2008)in patients with colorectal cancer, in gall bladder cancer Kumari et al.(2017), and in pancreatic adenocarcinoma Pietrasz et al.(2017). The present communication aimed to differentiate the cell free DNA levels (CF- DNA) and its integrity in prostate cancer patients and control group composed of benign prostate hyperplasia (BPH) and healthy persons. The relationships between the results and the clinicopathological findings were studied to evaluate the prognostic value of these markers in the detection of the included cases

\section{Patients and methods}

This is a cross sectional study that included 105 cases gathered during the time period from February 2014 to June 2015. A group of 50 patients were newly diagnosed for Prostate Cancer. They were recruited from the oncology outpatient clinic at National Cancer Institute - Cairo University. The stage of prostate cancer was classified using the TNM staging system, according to the American Joint Committee on Cancer (AJCC). Eligibility criteria for patient selection in our study were as follows: (1) valid informed consent form, (2) availability of blood samples before prostate biopsy and (3) availability of complete clinical and serum PSA data for each patient. Patients with other malignancies were excluded.In addition control group composed of 25 patients with BPH -who were recruited from the Urology Department at Kasr El-Aini Hospital, Cairo University-,and 30 apparently healthy men based on clinical and 
laboratory examinations with no history of malignant prostate disease, with PSA values less than $4 \mathrm{ng} / \mathrm{ml}$, and no symptoms of BPH at all.

\subsection{Ethics statement}

Informed written consent was taken from all participants prior to enrollment in this study according to Human Ethics Committee approval. The study protocol was reviewed and approved by the Ethical Committee of NCI., Cairo University (IRB No. 00004025) and (FWA No 00007284).

\subsection{Blood collection and DNA isolation}

Peripheral venous blood of $3 \mathrm{ml}$ was collected into EDTA containing tubes and processed within $2 \mathrm{~h}$ after venipuncture. To ensure cell-free plasma collection and to prevent cellular contamination, all EDTA-blood samples were centrifuged in 2 steps (3000 rpm for $10 \mathrm{~min}$ and then $12,000 \mathrm{rpm}$ for $10 \mathrm{~min}$ ). The cell-free plasmas were stored at $20^{\circ} \mathrm{C}$ until extraction. A total $50 \mu \mathrm{L}$ of DNA was extracted from $200 \mu \mathrm{L}$ of plasma using QIAamp DNA Blood Mini Kits (Qiagen, Valencia, CA) according to the manufacturer's instruction. DNA concentration was measured by Nanodrop spectrophotometer, and then stored at $20{ }^{\circ} \mathrm{C}$ until further analysis. Total PSA ( $t$ PSA)\&freePSA ,(f PSA) were measured by a solid-phase, two-site sequential chemiluminescent immune-metric assay performed on i1000 Architect auto-analyzer. The analyzer and Kits were purchased from Abott Architect diagnostics.

\subsection{Measurement of plasma CF-DNA concentration and DNA integrity}

The amount of DNA was determined by qRT- PCR technique through Step One RealTime PCR System (Applied Biosystems), according to the method of Umetani et al. (2006a) which uses a set of primers to amplify the consensus ALU sequence. A set of primers for the 115-bp amplicons were designed to amplify both shorter and long DNA fragments representing the total amount of CFDNA. A second set of primers for the 247-bp amplicons were also designed to amplify only long DNA fragments representing the DNA released from non- apoptotic cells. The sequences of the ALU 115 primers were forward 5' CCTGAGGTCAGGAGTTCGAG-3' and reverse 5' CCCGAGTAGCTGGGATTACA-3'; ALU 247 primers were forward 5' GTGGCTCACGCCTGTAATC-3' and reverse 5' CAGGCTGGAGTGCAGTGG-3'. DNA integrity was calculated as the ratio of concentrations in each assay (concentration of 247-bp fragments/concentration of 115-bp fragments). Because the annealing sites of template DNA is ALU115 are within the ALU247 annealing sites, the q-PCR ratio (DNA integrity) is 1.0 when not truncated and 0.0 when all templates DNA is completely truncated into fragments smaller than $247 \mathrm{bp}$. The standard reaction volume was $25 \mu \mathrm{l}$ consisting of $2 \mu \mathrm{l}$ of isolated template of DNA sample, 0.2 $\mu \mathrm{mol} / \mathrm{l}$ of forward and reverse primer, and $12.5 \mu \mathrm{l}$ of SYBR Green Master Mix (QIAGEN). The real-time PCR (q-PCR) was performed with precycling heat activation of DNA polymerase at $95{ }^{\circ} \mathrm{C}$ for $15 \mathrm{~min}$, followed by 50 cycles of denaturation at $94{ }^{\circ} \mathrm{C}$ for $15 \mathrm{~s}$, annealing at $60{ }^{\circ} \mathrm{C}$ for $30 \mathrm{~s}$, and extension at $72{ }^{\circ} \mathrm{C}$ for 
$30 \mathrm{~s}$. Following amplification, melting curve analysis was performed to confirm PCR product specificity and was carried out at $95^{\circ} \mathrm{C}$ for $5 \mathrm{~s}, 60{ }^{\circ} \mathrm{C}$ for $60 \mathrm{~s}$ and $95^{\circ} \mathrm{C}(0.11$ $\mathrm{C} / \mathrm{s}$ and 5 points per $\mathrm{C}$ ). The cfDNA concentrations were calculated by an external standard curve $(10 \mathrm{ng} / \mu \mathrm{l}, 1 \mathrm{ng} / \mu \mathrm{l}, 0.1 \mathrm{ng} / \mu \mathrm{l}, 0.01 \mathrm{ng} / \mu \mathrm{l}$ and $0.001 \mathrm{ng} / \mu \mathrm{l})$ of genomic DNA obtained from Promega (catalog number; 115701). For each plate, we used a negative control, and mean values were calculated from duplicate reactions.

\subsection{Statistical methods and sample size estimation}

The sample size was calculated based on the previous paper byUmetani (2006a)that reported an absolute difference in free DNA between cases and controls $0.08 \pm 0.09$ $\mathrm{ng} / \mu \mathrm{l}$ using power $80 \%$ and $5 \%$ significance level, 24 subject in each group would be sufficient. Data were analyzed using IBM SPSS advanced statistics version 22 (SPSS Inc., Chicago, IL). Numerical data were expressed as mean and standard deviation or median and range as appropriate. Chi-square test was used to examine the relation between qualitative variables. For not normally distributed quantitative data, comparison between two groups was done using Mann-Whitney test (non-parametric t-test). Comparison between 3 groups was done using Kruskal-Wallis test (nonparametric ANOVA) then post-Hoc "Schefe test" was used for pair-wise comparison based on Kruskal-Wallis distribution. The Receiver Operating Characteristic (ROC) curve was used for prediction of cut off values. All tests were two-tailed. A p-value $<0.05$ was considered significant.

\section{Results}

Characteristics of the studied groups are reported in Table 1. The mean age was 66.1 years (range 50-90) in patients with PC and 69.3 years (range 50-87) in patients with BPH. The mean age was 62.2 years (range 55-76) in control cases. There was no statistical difference in age between the three groups $(\mathrm{P}=0.411)$. The ALU115-qPCR marker was used for the quantification of circulating cell-free DNA (CF-DNA). Its concentration in patients with $\mathrm{PC}$ was significantly higher than that in patients with $\mathrm{BPH}$ and the control group $(\mathrm{P}<0.001)$. The ALU247-qPCR marker allows quantification of circulating cell-free DNA originated from tumor cells. Its concentration in patients with $\mathrm{PC}$ was significantly higher than that in patients with $\mathrm{BPH}$ and the control group ( $\mathrm{P}<0.001)$. The integrity of CF-DNA in patients with PC was also significantly higher than that in patients with $\mathrm{BPH}$ and the control group $(\mathrm{P}<$ 0.001).In patients with PC, no statistical association was found between ALU115 CFDNA and age $(\mathrm{P}=0.99)$ Gleason score $(\mathrm{P}=0.66)$, total serum PSA (tPSA, $\mathrm{P}=0.21)$, free serum PSA (fPSA)/tPSA $(\mathrm{P}=0.14)$ and stage $(\mathrm{P}=0.382)$. Also, no statistical association was found between ALU247 and age $(\mathrm{P}=0.786)$ Gleason score $(\mathrm{P}=$ 0.907), total serum PSA (tPSA, $\mathrm{P}=0.169)$, free serum PSA (fPSA)/tPSA $(\mathrm{P}=0.133$ ) and stage $(P=0,173)$. Furthermore, no statistical associations were found between integrity and age $(P=0.756)$, Gleason score $(P=0.302)$, tPSA $(P=0.610)$, free serum PSA (fPSA)/tPSA $(\mathrm{P}=0.823)$ and stage $(\mathrm{P}=0.264)$. In patients with $\mathrm{BPH}$, no statistical associations were found between CF-DNA or its integrity and age, tPSA, and $\mathrm{f} / \mathrm{tPSA}($ Table 1$)$. 
Table (1): Characteristics of the studied groups:

\begin{tabular}{|c|c|c|c|c|c|c|c|}
\hline & $\begin{array}{l}\text { No. of } \\
\text { patients }\end{array}$ & $\begin{array}{l}\text { CF-DNA-ALU115 } \\
\text { (Md.(range), ng/ } \mu \mathrm{l} \text { ) }\end{array}$ & $P$ value & $\begin{array}{l}\text { CF-DNA-ALU247 } \\
\text { (Md.(range), } \\
\text { ng/ } \mu \mathrm{l})\end{array}$ & $P$ value & $\begin{array}{l}\text { Integrity } \\
\text { (ALU247/ALU115) }\end{array}$ & $P$ value \\
\hline Prostate cancer & 50 & $\begin{array}{l}407.9 \\
(103.3-881.3)\end{array}$ & $<0.001 *$ & $\begin{array}{l}107.1 \\
(17.3-306.1)\end{array}$ & $<0.001 *$ & $\begin{array}{l}0.29 \\
(0.16-0.43)\end{array}$ & $<0.001^{*}$ \\
\hline $\begin{array}{l}\text { Age (years) } \\
\leq 65\end{array}$ & 26 & $\begin{array}{l}407.8 \\
(103.3-881.3)\end{array}$ & 0.992 & $\begin{array}{l}89.5 \\
(26.1-306.1)\end{array}$ & 0.786 & $\begin{array}{l}0.27 \\
(0.17-0.40)\end{array}$ & 0.756 \\
\hline$>65$ & 24 & $\begin{array}{l}402.1 \\
(108.0-785.4)\end{array}$ & & $\begin{array}{l}111.6 \\
(17.3-276.5)\end{array}$ & & $\begin{array}{l}0.29 \\
(0.16-0.43)\end{array}$ & \\
\hline $\begin{array}{l}\text { Gleason score } \\
5-6\end{array}$ & 8 & $\begin{array}{l}333.5 \\
(128.4-699.9)\end{array}$ & 0.668 & $\begin{array}{l}116.4 \\
(39.5-220.4)\end{array}$ & 0.907 & $\begin{array}{l}0.30 \\
(0.23-0.41)\end{array}$ & 0.302 \\
\hline $7-10$ & 42 & $\begin{array}{l}422.2 \\
(103.3-881.3)\end{array}$ & & $\begin{array}{l}100.8 \\
(17.3-306.1)\end{array}$ & & $\begin{array}{l}0.28 \\
(0.16-0.43)\end{array}$ & \\
\hline $\begin{array}{l}\operatorname{tPSA}(\mathrm{ng} / \mathrm{ml}) \\
\leq 10\end{array}$ & 6 & $\begin{array}{l}312.7 \\
(108.0-422.2)\end{array}$ & 0.210 & $\begin{array}{l}79.4 \\
(17.3-112.9)\end{array}$ & 0.169 & $\begin{array}{l}0.28 \\
(0.16-0.34)\end{array}$ & 0.610 \\
\hline$>10$ & 44 & $\begin{array}{l}426.3 \\
(103.3-881.3)\end{array}$ & & $\begin{array}{l}112.9 \\
(26.1-306.1)\end{array}$ & & $\begin{array}{l}0.29 \\
(0.17-0.43)\end{array}$ & \\
\hline $\begin{array}{l}\mathbf{f} / \mathbf{t} \text { PSA }(\%) \\
<15\end{array}$ & 25 & $\begin{array}{l}251.4 \\
(103.3-870.1)\end{array}$ & 0.140 & $\begin{array}{l}86.3 \\
(26.1-246.9)\end{array}$ & 0.133 & $\begin{array}{l}0.29 \\
(0.19-0.43)\end{array}$ & 0.823 \\
\hline$\geq 15$ & 25 & $\begin{array}{l}541.9 \\
(108.0-881.3)\end{array}$ & & $\begin{array}{l}118.4 \\
(17.3-306.1)\end{array}$ & & $\begin{array}{l}0.28 \\
(0.16-0.41)\end{array}$ & \\
\hline $\begin{array}{l}\text { Metastatic } \\
\text { Yes }\end{array}$ & 28 & $\begin{array}{l}662.9 \\
(208.8-881.3)\end{array}$ & $<0.001 *$ & $\begin{array}{l}167.9 \\
(39.0-306.0)\end{array}$ & $<0.001 *$ & $\begin{array}{l}0.26 \\
(0.17-0.39)\end{array}$ & $0.05^{*}$ \\
\hline No & 22 & $\begin{array}{l}187.9 \\
(103.3-373.8)\end{array}$ & & $\begin{array}{l}54.5 \\
(17.3-119.8)\end{array}$ & & $\begin{array}{l}0.30 \\
(0.16-0.43)\end{array}$ & \\
\hline $\begin{array}{l}\text { Stage } \\
\text { I, II }\end{array}$ & 10 & $\begin{array}{l}536.5 \\
(108.0-848.1)\end{array}$ & 0.382 & $\begin{array}{l}162.1 \\
(17.3-306.0)\end{array}$ & 0.173 & $\begin{array}{l}0.30 \\
(0.16-0.39)\end{array}$ & 0.264 \\
\hline III, IV & 40 & $\begin{array}{l}333.52 \\
(103.3-881.3)\end{array}$ & & $\begin{array}{l}95.2 \\
(26.1-276.5)\end{array}$ & & $\begin{array}{l}0.27 \\
(0.17-0.43)\end{array}$ & \\
\hline ВPH & 25 & $\begin{array}{l}17.2 \\
(3.2-74.5)\end{array}$ & & $\begin{array}{l}1.5 \\
(0.3-9.1)\end{array}$ & & $\begin{array}{l}0.10 \\
(0.06-0.15)\end{array}$ & \\
\hline $\begin{array}{l}\text { Age (years) } \\
\leq 65\end{array}$ & 12 & $\begin{array}{l}12.6 \\
(3.2-74.5)\end{array}$ & 0.852 & $\begin{array}{l}1.4 \\
(0.4-8.1)\end{array}$ & 0.844 & $\begin{array}{l}0.12 \\
(0.07-0.15)\end{array}$ & 0.163 \\
\hline$>65$ & 13 & $\begin{array}{l}19.4 \\
(4.8-71.3)\end{array}$ & & $\begin{array}{l}1.5 \\
(0.3-9.1)\end{array}$ & & $\begin{array}{l}0.10 \\
(0.06-0.15)\end{array}$ & \\
\hline $\begin{array}{l}\text { tPSA }(\mathrm{ng} / \mathrm{ml}) \\
0-4\end{array}$ & & $\begin{array}{l}9.6 \\
(3.2-54.8)\end{array}$ & 0.518 & $\begin{array}{l}1.3 \\
(0.3-8.2)\end{array}$ & 0.844 & $\begin{array}{l}0.13 \\
(0.07-0.15)\end{array}$ & 0.163 \\
\hline $4.01-10$ & & $\begin{array}{l}17.2 \\
(5.3-69.4)\end{array}$ & & $\begin{array}{l}1.5 \\
(0.7-8.6)\end{array}$ & & $\begin{array}{l}0.11 \\
(0.07-0.14)\end{array}$ & \\
\hline$>10$ & & $\begin{array}{l}52.1 \\
(4.8-74.5)\end{array}$ & & $\begin{array}{l}5.2 \\
(0.4-9.1)\end{array}$ & & $\begin{array}{l}0.09 \\
(0.06-0.13)\end{array}$ & \\
\hline $\begin{array}{l}\text { f/t PSA }(\%) \\
<15\end{array}$ & & $\begin{array}{l}21.68 \\
(4.8-74.5)\end{array}$ & 0.419 & $\begin{array}{l}1.8 \\
(0.4-8.6)\end{array}$ & 0.522 & $\begin{array}{l}0.09 \\
(0.07-0.14)\end{array}$ & 0.419 \\
\hline$\geq 15$ & & $\begin{array}{l}8.8 \\
(3.2-71.2)\end{array}$ & & $\begin{array}{l}1.2 \\
(0.3-9.1)\end{array}$ & & $\begin{array}{l}0.11 \\
(0.06-0.15)\end{array}$ & \\
\hline
\end{tabular}

Md.: Median, BPH: Benign Prostate Hypertrophy, tPSA: total Prostate specific Antigen, fPSA: free Prostate Specific Antigen, $\mathrm{P}<0.05$ is significant. 


\subsection{Characteristics of metastatic group}

Twenty-eight patients (56\%) with prostate cancer had bone metastasis confirmed by CT scan, bone scintigraphy, X-ray or magnetic resonance. There were highly significant differences in ALU115-qPCR (cfDNA) between metastatic group (median: $662.9 \mathrm{ng} / \mu \mathrm{l}$, range $208.8-881.3 \mathrm{ng} / \mu \mathrm{l}$ ) and non-metastatic (median: $187.9 \mathrm{ng} / \mu \mathrm{l}$, range (103.3-373.8) ng/ $\mu$ l) with $(\mathrm{P}<0.001)$ Table( 2$)$. The ALU247-qPCR marker showed highly significant differences between metastatic group and non -metastatic $(\mathrm{P}<$ 0.001). Also, its integrity showed significant differences between metastatic group and non-metastatic $(\mathrm{P}<0.05)$ Fig. ( 1$)$. However, no association was found between these markers and the other clinicopathological findings, such as Gleason score,tPSA and (fPSA)/tPSA (Table2). ROC curve analysis of CFDNA levels of ALU115\&247, and their integrity were carried out to differentiate metastatic samples from non-metastatic (Table 3).Fig. 2(A) represents CFDNA produced byqALU115,theAUC was 0.981 with a sensitivity of $96.4 \%$ and a specificity of $86.4 \%$, while the ALU247-qPCR marker showed AUC $=0.934$ with a sensitivity of $92.9 \%$ and a specificity of $72.7 \%$, fig.2(B).The integrity of CF-DNA demonstrated a sensitivity of $64.3 \%$ and a specificity of $63.6 \%, \mathrm{AUC}=0.657$,fig. 2 (C) and Table 3.

Table (2) Relation between patient's characteristics with ALU115, ALU247 and integrity in metastatic and non-metastatic group:

\begin{tabular}{llll}
\hline & $\begin{array}{l}\text { Metastatic(28) } \\
\text { Md.(range) }\end{array}$ & $\begin{array}{l}\text { Non-metastatic(22) } \\
\text { Md.(range) }\end{array}$ & P- Value \\
\hline Age (years) & 65.0 & 66.5 & 0.660 \\
& $(55.0-90.0)$ & $(50.0-88.0)$ & \\
Gleason score & 8.0 & 7.0 & 0.190 \\
& $(5.0-10.0)$ & $(6.0-10.0)$ & 0.265 \\
tPSA(ng/ml) & 31.85 & 76.0 & \\
& $(9.14-2000)$ & $(4.10-6637.0)$ & 0.645 \\
f/t PSA (\%) & 0.17 & 0.135 & $<0.001^{*}$ \\
Conc115 & $(0.06-0.4)$ & $(0.09-0.46)$ & \\
& 662.93 & 187.92 & $<0.001^{*}$ \\
Conc247 & $(208.84-881.30)$ & $(103.30-373.87)$ & $0.05^{*}$ \\
Integrity & 167.96 & 54.50 & \\
& $(39.0-306.09)$ & $(17.31-119.86)$ & 0.299 \\
\hline
\end{tabular}


Table (3) Diagnostic accuracy of the studied tumor markers between metastatic and non-metastatic either single or combined.

\begin{tabular}{llllll}
\hline & Sensitivity (\%) & Specificity (\%) & PPV (\%) & NPV (\%) & $\begin{array}{l}\text { Diagnostic } \\
\text { accuracy }\end{array}$ \\
\hline ALU115 $^{\text {a }}$ & 96.4 & 86.4 & 90.0 & 95.0 & 92.0 \\
ALU247 $^{\text {b }}$ & 92.9 & 72.7 & 81.3 & 88.9 & 84.0 \\
Integrity $^{\mathrm{c}}$ & 64.3 & 63.6 & 69.2 & 58.3 & 64.0 \\
T-PSA $^{\text {d }}$ & 92.9 & 18.2 & 59.1 & 66.7 & 60.0 \\
T-PSA+ALU115 & 89.3 & 90.90 & 92.6 & 87.0 & 90.0 \\
T-PSA+ALU247 & 89.3 & 81.8 & 86.2 & 85.7 & 86.0 \\
T-PSA+Integrity & 57.1 & 68.2 & 69.6 & 55.6 & 62.0 \\
\hline
\end{tabular}

PPV positive predictive value, NPV negative predictive value, LR+ positive likelihood ratio, LR- negative likelihood ratio,T-PSA total prostate specific antigen.
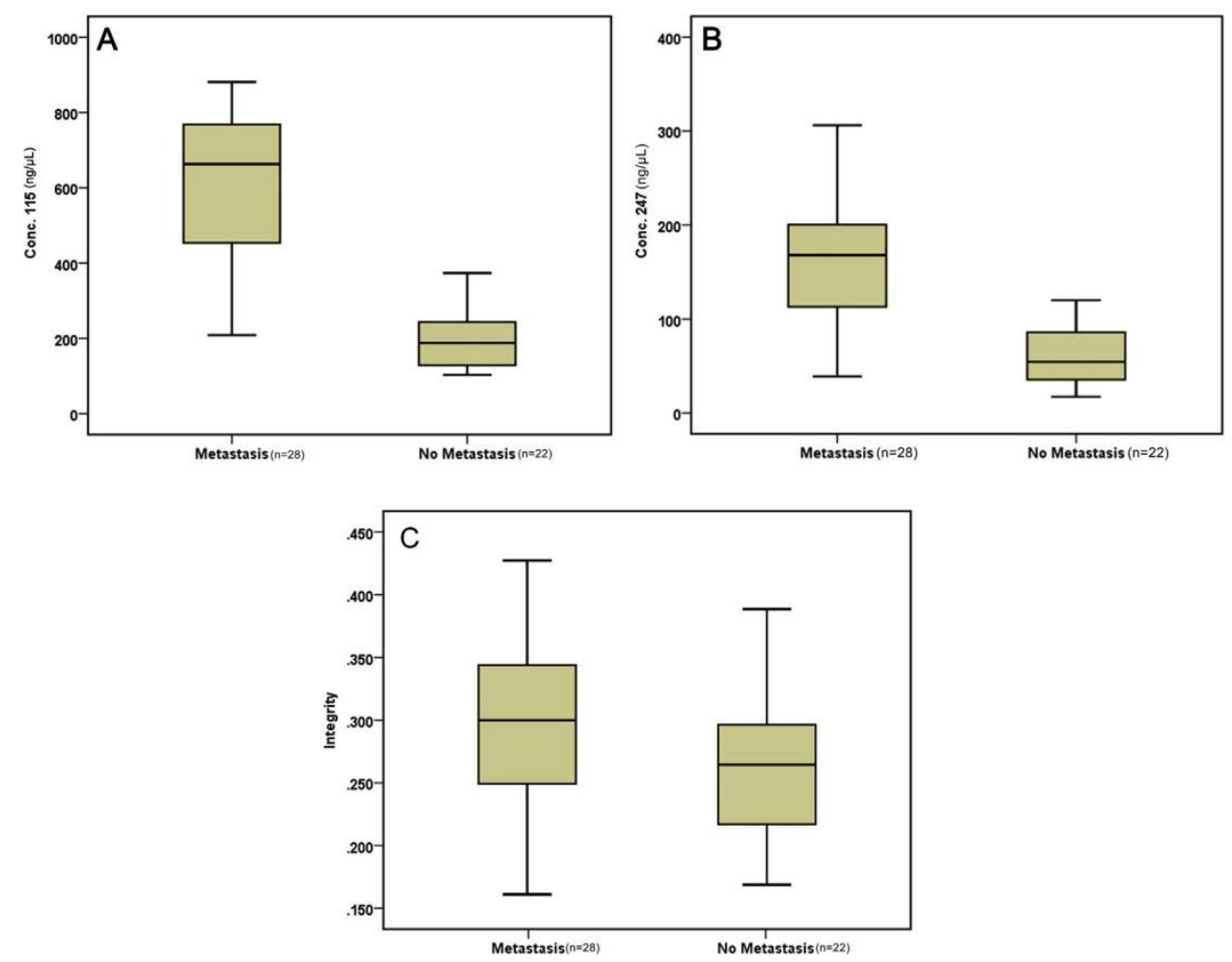

Figure 1:Box plots of the DNA concentrations in metastatic PC and non-metastatic, (A) ALU115, (B) 247 and DNA integrity (C). 

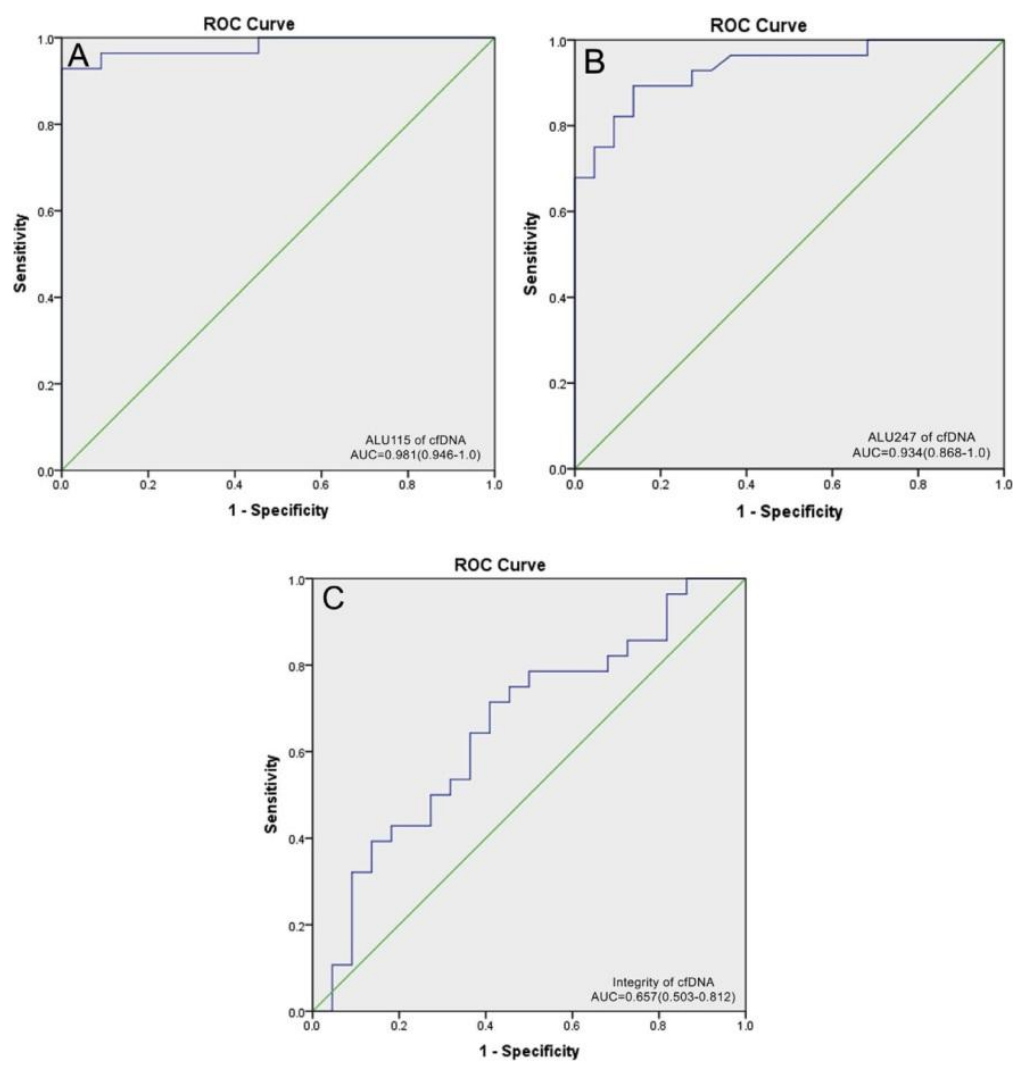

Figure 2: Receiver operating characteristic curve for distinguishing metastatic prostate cancer by using ALU 115 (A), ALU247 (B), and DNA integrity (C).

\section{Discussion}

The present study revealed high percentage of PC patients, (88\%) had t PSA level more than $10 \mathrm{ng} / \mathrm{ml}$; while $44 \%$ of BPH patients had a value between $4-10$ $\mathrm{ng} / \mathrm{ml}$. Most of the control subjects had $0.4 \mathrm{ng} / \mathrm{ml}$. These results are in a good agreement with that observed by Aus et al. (2004). The data from PC patients in a screening program based on PSA measurement was only $34 \%$ for men with PSA values between $3-6 \mathrm{ng} / \mathrm{ml}, 44 \%$ for those with PSA between $6-10$ and $71 \%$ with PSA > $10 \mathrm{ng} / \mathrm{ml}$. Also Gordian et al. (2010) believed that tPSA above $10 \mathrm{ng} / \mathrm{ml}$ is associated with a high likelihood of PC, and a prostate biopsy is commonly recommended in this situation. They added the results with a high negative predictive value of $93.1 \%$ adding CF-DNA concentrations, spare $33 \%$ of patients with PSA $<10$ $\mathrm{ng} / \mathrm{ml}$ of unwanted prostate biopsies. This finding is of major clinical significance because of the fact that $65 \%$ to $75 \%$ of patients with intermediate PSA levels between 4 to $10 \mathrm{ng} / \mathrm{ml}$ are subjected to unnecessary prostate biopsies. The present study revealed that $50 \%$ of $\mathrm{PC}$ patients had $\mathrm{F} / \mathrm{t}$ ratio more than $15 \%, 64 \%$ of $\mathrm{BPH}$ were less than $15 \%$, while all of the control subjects were less than $15 \%$. With this respect, the introduction of FPSA testing has presented a greater level of specificity in identifying early PC (Catalona et al., 2000). Moreover, using the cut-off value of less than $25 \%$ FPSA for diagnosing patients with PCOmar et al. (2009) found that majority of the PC patients have a ratio of fPSA/ tPSA more than $25 \%$ and a significantly higher level of tPSA when compared with patients with BPH. Unexpectedly, the fPSA values 
were high in PC compared to BPH. Consequently, ratio of fPSA / tPSA was found not to be sensitive and specific in diagnosing PC at the cut-off value of $25 \%$ so,he concluded that total PSA is a more useful biochemical test for diagnosing PC in the studied patients.

In the current study CF-DNA levels were measured from plasma of individuals (PC, BPH\& healthy controls)under investigation, using a quantitative real - time PCR method. Several published data revealed higher levels in CFDNA in serum than that found in plasma. The differences may reach 14 - fold (Lee et al., 2001, and Umetaniet al., 2006a\&b). Other investigators detected lower differences of 2 - 3 times (Thijssen et.al., 2002 and Jung et al., 2004). So far, Thijssen et al, (2002) considered that plasma DNA better reflects the in vivo concentrations of cell free DNA than serum DNA.

In this study CF.DNA levels produced by ALU 115 and/or 247 were higher in PC patients than that of BPH. Statistically the difference between the two studied groups was significantly high $\quad(\mathrm{P}<0.001)$. Such results are in a good agreement with that obtained by several authors (Allen et al., 2004; Felix et al., 2006 and Altimari et al., 2008). Thus Allen et al. (2004) demonstrated that PC patients and prostate intraepithelial neoplastic had significant levels of DNA when compared with BPH.

Further,Felix et al. (2006) observed that the median plasma CF-DNA was $26.7 \mathrm{ng} / \mathrm{ml}$ and $709 \mathrm{ng} / \mathrm{ml}$ in BPH and PC respectively. These values are exceeded by 3 or 4 times the DNA yields reported by other studies (Wu et al., 2002, and Jung et al., 2004). So, Felixet al. suggested that this discrepancy might be due to the different DNA preparation and extraction techniques.

PC may spread to the bones, liver or lungs. It is rarer for it to spread to other organs such as brain, (Robinson, 2015). Prostate cancer prefers to grow in specific areas such as lymph nodes or, in the ribs, pelvic bones and spine.

The present results revealed high significant differences in CF - DNA produced by ALU 115 and/or ALU 247 QPCR (CF- DNA) between metastatic patients to non-metastatic $(\mathrm{P}<0.001)$. Moreover, the integrity showed significant differences between both studied groups. The present data coincide with previous findings obtained by many investigators. Thus, Umetani et al. (2006 a)detected that mean serum DNA integrity was positively correlated to size of invasive cancers and in the presence of lymphovascular invasion or lymph node metastasis. Also Bastian et al. (2007) observed that the amount of CF-DNA in patients with metastatic PC was significantly higher compared with men with localized PC. In addition Schwarzenbach et al. (2009) found that the plasma DNA levels significantly correlated with the diagnostic of localized and metastasized PC and, with the tumor stage of the studied patients. Such data indicate that genetic analysis of CF-DNA might become a valuable new source for monitoring metastatic progression in cancer patients and may therefore contribute to the molecular staging of PC. 
On the contrary, Jung et al. (2004) found that patients with localized cancer had DNA plasma within the reference interval. Increased DNA was found in patients with lymph node and distant metastasis and also in BPH. So he believed that plasma DNA has a limited validity as metastatic marker in PC patients.

Considering the correlations between metastatic and non- metastatic groups, no statistical significant was found between Gleason score, t PSA, F/t PSA.

Nevertheless, high differences were found between CFDNA of ALU 115 and ALU 247. It is of interest to mention that ALU 115 QPCR level was found to be higher than that ALU 247 q PCR (P < 0.001). As a general remark, no statistical differences were obtained between them and the other clinicopathological findings such as Gleason Score, t PSA and F/t ratio. Many published reports pointed to the relationships between CFDNA levels and the clinical characteristics of patients with cancer disease. Our results are in agreement with that obtained byJahr et al. (2001); Sai et al. (2007); Gordian et al., (2010); Delgado et al. (2013)

Controversial results were presented by Feng et al. (2013). Among the PC patients, he observed significant differences of CFDNA level in groups with different Gleason score, t PSA and F/t PSA except age. This result suggested that CFDNA level might be associated with progression of PC. In addition no statistical associations were found between integrity and age, Gleason score, and t PSA except F/t PSA. This finding may be explained by the fact that integrity of CFDNA was more associated with necrosis of prostate cancer.

On the other hand,Wroclawski et al. (2013) detected no statistical significant correlation between CFDNA levels at study entry with PSA, Gleason score, stage and biochemical recurrence free survival (BRFS). However, with a mean follow-up of 13.5 months, they could observe a significant shorter BRFS for patients with at least one value above $140 \mathrm{ng} / \mathrm{ml}$ of CFDNA during follow-up potential tool for the followup of patients with PC.

The diagnostic performance of a test, to discriminate diseased cases from normal cases is evaluated by using Receiver operating characteristic (ROC) curve analysis (Metz, 1978; Zweig\& Campbell, 1993). Roc curves can also be used to compare the diagnostic performance of two or more laboratory of diagnostic tests (Griner et al. 1981). Through ROC curve analysis the obtained results suggest CFDNA a highly sensitive and specific marker to discriminate metastatic samples from non- metastatic. Evaluation of CFDNA level with ALU 115 q PCR achieved sensitivity and specificity of $96.4 \%$ and $86.4 \%$ and AUC 0.981 which are significantly higher than those obtained by ALU 247 q PCR.

With this respect Umetani et al. (2006a) observed that the absolute level of serum DNA measured as ALU 115 q PCR value was elevated on average in females with AJCC stage 0-1V primary breast cancers. However through using ROC analysis they found that the serum DNA integrity had a higher correlation coefficient value 
with tumor progression and also associated with lymphovascular invasion and lymph node metastasis.

Also Sai et al. (2007) examined the plasma DNA concentration. of short and long fragments of GC patients by a q PCR method. The median concentraion. and its integrity were significantly higher in GC patients compared to normal controls in both the short and long assays. Moreover, the difference was more significant in the longer fragment assay. Patients with advanced- stage disease had a significantly higher DNA concentration. than those with early-stage disease. According toSai et al. the plasma CFDNA is not an idealsingletumor marker because the results showed that elevated free DNA levels could be detected only in a subset of cancer patients. Its combination with other established markers may constitute a better prognostic factor

In contrast the observations obtained by Kumari et al. (2017)suggest CFDNA as a highly sensitive and specific marker to discriminate GBC patients from cholecystitis and healthy controls. They found that patients with cholecystitis have higher CFDNA compared to normal, but have significantly low CFDNA when compared to GBC. They added a concomitant evaluation of CFDNA levels may assist to suspecting malignancy. Also the results indicate that CFDNA level in patients do not relate with primary tumor size and metastatic. However, patients with lymph node involvement and jaundice presented significantly higher level of CFDNA.

On the other hand,Cargnin et al. (2017)support the clinical validityof quantitative analysis of CFDNA for the prediction of lung cancer survival. Though, in their opinion the establishment of a robust standardized method for determination of optimal cutoff thresholds is required to define the clinical relevance of CFDNA quantification for lung cancer.

In conclusion the present study revealed the effectiveness ofCFDNA levels produced by using ALU 115 and 247q PCR as a marker in PC.Significant differences were obtained in PC patients comparing to $\mathrm{BPH}$, and highly significant differences were picked out between both groups and the normal controls. In addition by using ALU 115 q PCR the metastatic samples could be distinguished from the nonmetastatic.

Actually, lots of literature indicated the promising diagnostic value of CFDNA in the administration of PC. However the literature on the accuracy of CFDNA detection of PC has been in conflict. On the other hand the use of PSA in combination with digital rectal examination for early diagnosis in well informed patients is less controversial and widely used in clinical practice. So, from the literatures and from the present results, it can be concluded that, in addition to the conventional usedexaminations, CFDNA level determination can be used as adjuvant tool for PC screening. 


\section{References}

ACS, American Cancer Society, What are the risk factors of prostate cancer? http./www.Cancer-org/cancer/prostate. Cancer/detailed guide/prostate cancer-riskfactors.2012

ACS-American Cancer Society. Cancer Facts \& Figures, Available at http://www.cancer.org/acs/groups/content/@epidemiologysurveilance documents/document/acspc-026238 .pdf.2010Accessed: January 9, 2011.

Allen, D.; Butt, A.; Cahill, D.; Wheeler, M.; Popert, R.,andSwaminathan, R.Role of cell-free plasma DNA as a diagnostic marker for prostate cancer. Ann N Y AcadSci..1022:76-80.2004.

Altimari, A; Grigioni, A. D.; Benedettini, E. et al. Diagnostic role of circulating free plasma DNA detection in patients with localized prostate cancer. Am. J. Clin. Pathol.., 129(5): 756 - 762.2008.

AUS, G.; Becker, C.; Franze, N. S., Lilja, H.; Lodding, P.; and Hugosson.I.Cumulative prostate cancer risk assessment with the aid of the free - to total prostate Specific antigen ratio. Eur. Urol.., 45: 160 -165. 2004.

Barrett, K.E.; Barman, S.M.; Boitano, S.; and Brooks H. L. Ganong's review of medical physiology, 23rd edn,. McGraw Hill LANGE, Middle East edn P 402 \& 406.2010.

Bastian,P.J.;Palpatta,G. S.; Yegnasubramanian, S.; Lin,X.; Rogers,C. G.; Mangold,L.A.;et al.Prognostic value of preoperative serum cell-free circulating DNA in men with prostate cancer undergoing radical prostatectomy. Clin. Cancer Res., 13 (18):5361-5367, 2007.

Bostwick,D.G. ;Burke, H. B.;Djakiew D. ;Euling, S. ; Ho,S.M.; Landolph,J. ; et al. Human prostate cancer risk factors. Cancer,101(10):2371-2490.2004.

Cancer-Net Editorial Board.Prostate cancer risk factors and prevention. http. I www.cancer.net/cancer-types/prostate cancer/risk-factors-andprevention, 2016.

Cao, X. L.; Gao, J. P. ; Han, G.; Tang, J.; and Hong, B.F. Relationship between screening by stratifying cases into groups on prostate specific antigen level and the positive rate of trans rectal ultrasound guided systematic sextant prostate biopsy. ZhonghuaWaiKeZaZhi.,44 (6):372-375.2006.

Cargnin,S.; Canonico,P.L.; Genazzani, A. A. ,and Terrazzino,S. Quantitative analysis of circulating cell-free DNA for correlation with lung cancer survival: A systematic review and meta-analysis. J. Thorac. Oncol.12(1):43-53.2017.

Catalona, W. J.; Southwick, P. C.; Slawin, K. M. et.al. . Comparison of percent free PSA, PSA density and age specific PSA cutoffs for prostate cancer detection and staging. Urology,56(2): 255 - 260 (Pub med).2000.

Chan, K. C.; Leung, S. F.; Yeung, S. W.; Chan, A. T. , and Lo, Y.M.Persistent aberrations in circulating DNA integrity after radiotherapy are associated with poor prognosis in naso pharyngeal carcinoma. Clin. Cancer Res., 14 (13):4141-4145, 2008. 
Delgado, P. O.; Alves, B. C.; Gehrke, Fde. S.; Kuniyoshi, R. K.; Wroclavski, M. L.; DelGiglio, A.; et al. Characterization of cell-free circulating DNA in plasma in patients with prostate cancer. Tumor Biol., 34(2):983-986.2013.

Elabbady, A.: Eid, A. ;Fahmy, A. andKoth, A. F. Pattern of prostate cancer presentation among the Egyptian Population: A study in a single tertiary care center. Cent. European J. Urol.,67 (4):351-356.2014.

Felix, K. H.; Chun, S.; Imke, M.; Lange, I.; Fridrich, M. G. Embersdobler, A. et. al.Circulating tumor-associated plasma DNA represents an independent and informative predictor of prostate cancer. J. Compilation BJU. Internat.,98: 544 548.2006.

Feng J, Gang F, Li X, Jin T, HoubaoH, Yu C, et al. Plasma cell-free DNA and its DNA integrity as biomarker to distinguish prostate cancer from benign prostatic hyperplasia in patients with increased serum prostate-specific antigen. Int. Urol. Nephrol.,45(4):1023-1028.2013.

Gordian, E.; Ramachandran, K.; Reis, I. M. ;Manoharan,M. ; Soloway, M. S. andSingal, R. Serum free circulating DNA is auseful biomarker to distinguish benign versus malignant prostate disease. Cancer Epidemiol- Biomarkers Prev., 19 (8):19841991.2010.

Griner, P. F. ;Mayewski, R. J.;Mushlin,A. I.; and Greenland, P. Selection and interpretation of diagnostic tests and procedures. Ann.Intern.Med., 1981, 94(4/2) 557 $-592.1981$

Jahr,S. ;Hentze, H. ; Englisch, S. ; Hardt, D.; Fackelmayer, F. O.; Hesch, R. D. ; et al. DNA fragments in the blood plasma of cancer patients: Quantitation and evidence for their origin from apoptotic and necrotic cells. Cancer Res., 61 (4): 16591665.2001.

Robinson,J.What is metastatic prostate cancer? Web MD Medical Reference Wikipedia.2015.

Jung, K.; Stephan, C.; Lewandowski, M.; Klotzek, S.; Jung, M.; Kristiansen, G., et al. Increased cell free DNA in plasma of patients with metastatic spread in prostate cancer. Cancer Lett.,205(2):173-180.2004.

Kumari,S.;Tewari,S.,Husain,N.;Singhal,A.andLohani,A. Quantification of circulating free DNA as a diagnostic marker in gall bladder cancer. Pathol. Oncol. Res.,23: 91-97.2017.

Lee, T. H.; Montalvo, L., Chrebtow, V., and Busch, M. P. Quantition of genomic DNA in plasma and serum samples higher concentrations of genomic DNA found in serum than in plasma. Transfusion, 41: $276-282.2001$.

Metz, C. E Basic principles of ROC analysis seminars in unclear medicine. 8: 283 298. 1978.

Omar, J.; Jaafar, Z., and Abdullah, R. M.A pilot study on percent free prostate specific antigen as an additional tool in prostate cancer screening. Malays J. Med Sci.,16(1):44 - 47.2009. 
Pietrasz, D.; Pecuchet, N.; Garlan, F. et al. Plasma circulating tumor DNA in pancreatic cancer patients is a prognostic marker. Clin. Cancer Res., 2017, 23(1):116123.2017 .

Sai, S.; Ichikawa, D.; Tomita, H. ; Ikoma, D.; Tani, N.; Ikoma, H.et al.Quantification of plasma cell free DNA in patients with gastric cancer. Anticancer Res.,(4C): 2747-2751.2007.

Schwarzenbach H1, Alix-Panabie`res C, Mu“ller I, Letang N, Vendrell JP, Rebillard X, et al. Cell-free tumor DNA in blood plasma as a marker for circulating tumor cells in prostate cancer. Clin. Cancer Res.,15(3):1032-1038.2009.

Schwarzenbach, H.; Stoehlmacher, J.; Pantel, K.; Goekkurt, E.Detection and monitoring of cell-free DNA in blood of patients with colorectal cancer. Ann N Y Acad. Sci.,1137:190-196.2008.

Souto, C. A. V.; Fonseca, G. N.; Carvalhal, G. F.; Barata, H. S.; Souto, J. CS. and Berger, M.,SociedadeBrasileira de urologiaCancer de prostate. Marcadores Tumorais.2006 http:// www. Projetodiretrizes.org.br.5 volume/09CancerMar.pdf.2006,Accessed Oct.2012.

Thijssen, M. A.; Swinkles, D. W.; Ruers, T. J.; and Dekok, J. B. Differences between free circulating plasma and serum DNA in patients with colorectal liver metastases. Anticancer Res., 22: 421 - 425.2002.

Umetani, N.;Giuliano, A. E.; Hiramatsu, S.H.; Amersi, F.; Nakagawa, T.; Martino, S., et al. Prediction of breast tumor progression by integrity of free circulating DNA in serum. J.Clin.Oncol., 24(26):4270-4276.2006 a.

Umetani, N.; Kim, J.; Hiramatsu, S.; Reber, H. A.; Hines, O. J.; Bilchik, A. J., et. al. Increased integrity of free circulating DNA in sera of patients with colorectal or periampullary cancer: direct quantitative PCR for ALU repeats. Clin Chem., 52(6):1062-1069.2006 b.

Wroclawski, M. L.; Sperpa - Neto, A., and Fonseca, F. L. A. Cell - free plasma DNA as biochemical biomarker for the diagnosis and follow up of prostate cancer patients. Tumor Biol.,34(5) 2921 - 2927.2013.

Wu. T. L.; Zhang. D.; Chia, J. H.; Tsao, K. H.; San, C. F., and Wu, J. T. Cell-free DNA: Measurement in various carcinomas and establishment of normal reference range. Clin. Chim. Acta.,321: 77 - 87.2002.

Zweig M.H.and Campbell G. Receiver operating characteristic (ROC) plots: A fundamental evaluation tool in clinical medicine. Clinical chemistry, 1993, 39: 561 577.1993. 
